UDC 338.12:332.7

\author{
Vladimir KARPOV \\ PhD in Economics, Associate Professor of Economics, Law and Business Management Department, \\ Odessa National Economic University, Ukraine, e-mail:0682636461karpov@gmail.com, \\ ORCID ID: http://orcid.org/0000-0002-9968-8380
}

\title{
DOES NPV REFLECT THE REAL PROJECT EFFICIENCY?
}

Karpov, V. (2019). Does NPV reflect the real project efficiency? Ed.: M. Zvieriakov (ed.-in-ch.) and others [Chy vidbyvaie NPV realnu efektyvnist proektu?; za red.: M. I. Zvieriakova (gol. red.) ta in.], Socio-economic research bulletin; Vìsnik socìal'no-ekonomičnih doslìdžen' (ISSN 2313-4569), Odessa National Economic University, Odessa, No. 1 (69), pp. 108-117.

\begin{abstract}
The article considers the theoretical and practical problems of the project efficiency calculating on the example of one of its main estimated indicators - NPV (net present value). The discounted project performance indicators used by most theorists and analysts in some cases do not reflect the real project profitability (unprofitability). The net present value calculation for various options for the nature of projects cash flow is shown in a number of simulated examples. It is shown that for some unprofitable projects the net present value indicator, nevertheless, indicates a positive effect, which contradicts with idea of this indicator using for evaluating of alternative projects efficiency. This situation is typical for projects with long-term loans and quick returns on capital investments. We believe that this situation arises as a result of the fact that costs include in the calculations of performance indicators, which are discounted simultaneously with revenues and thus numerically increase the discounted level of project profitability (when discounting a negative amount of costs, total profitability increases). Although, if we proceed from the theory of money value over time, exactly costs create a future value - PV. The article analyzes the considered contradictions of performance indicators of various project options and proposes a new indicator for projects efficiency evaluating.
\end{abstract}

Keywords: cash flow; effective project; effectiveness curve; net present value.

\section{Володимир Анатолійович КАРПОВ}

кандидат економічних наук, дочент кафедри економіки, права та управління бізнесом, Одеський наиіональний економічний університет, Україна, е-таil:0682636461karpov@gmail.com,

ORCID ID: http://orcid.org/0000-0002-9968-8380

\section{ЧИ ВІДБИВАС NPV РЕАЛЬНУ ЕФЕКТИВНІСТЬ ПРОЕКТУ?}

Карпов, В. А. Чи відбиває NPV реальну ефективність проекту? Вісник соціально-економічних досліджень : зб. наук. праць / За ред. : М. І. Звєрякова (голов. ред.) та ін. Одеса : Одеський національний економічний університет. 2019. № 1 (69). С. 108-117.

\begin{abstract}
Анотація. У статті розглянуто теоретичні та практичні проблеми розрахунків ефективності проекту на прикладі одного з головних його оціночних показників - NPV (net present value - чистий дисконтований дохід). Використовувані більшістю теоретиків і аналітиків дисконтовані показники ефективності проектів у низиі випадків не відображають реальну прибутковість (збитковість) проекту. Розрахунок чистого дисконтованого доходу для різних варіантів за характером грошового потоку проектів наведено на деяких змодельованих прикладах. Показано, щзо для деяких збиткових проектів показник чистого дисконтованого доходу вказує, проте, на позитивний ефект, щзо входить в протиріччя з ідеєю використання даного показника для оцінки ефективності альтернативних проектів. Така ситуація характерна для проектів 3 довгостроковими кредитами і швидкою віддачею від капітальних вкладень. Вважаємо, щзо подібна ситуація виникає внаслідок того, щ⿻ до розрахунків показників ефективності включаються витрати, які дисконтуються одночасно з доходами $i$ тим самим, чисельно збільшують дисконтований рівень прибутковості проекту (при дисконтуванні негативної величини витрат збільшується сумарна прибутковість). Хоча, якщз виходити з теорії цінності грошей у часі, саме витрати народжують майбутню вартість - PV. У статті проаналізовано розглянуті протиріччя показників ефективності різних варіантів проектів і запропоновано новий показник оцінки ефективності проектів.
\end{abstract}

Ключові слова: грочовий потік; ефективний проект; крива ефективності; чиста приведена вартість.

\section{Владимир Анатольевич КАРПОВ}

кандидат экономических наук, доцент кафедры экономики, права и управления бизнесом, Одесский национальный экономический университет, Украина, e-mail: 0682636461karpov@gmail.com, ORCID ID: http://orcid.org/0000-0002-9968-8380 


\title{
ОТРАЖАЕТ ЛИ NРУ РЕАЛЬНУЮ ЭФФЕКТИВНОСТЬ ПРОЕКТА?
}

Карпов, В. А. Отражает ли NPV реальную эффективность проекта? Вестник социально-экономических исследований : сб. науч. трудов / Под ред. : М. И. Зверякова (глав. ред.) и др. Одесса : Одесский национальный экономический университет. 2019. № 1 (69). С. 108-117.

\begin{abstract}
Аннотация. В статье рассмотрены теоретические и практические проблемы расчетов эффективности проекта на примере одного из главных его оченочных показателей - NPV (nеt present value - чистый дисконтированный доход). Используемые больиинством теоретиков и аналитиков дисконтированные показатели эффективности проектов в ряде случаев не отображают реальную прибыльность (убыточность) проекта. Расчет чистого дисконтированного дохода для различных вариантов по характеру денежного потока проектов приведен на ряде смоделированных примеров. Показано, что для некоторых убыточных проектов показатель чистого дисконтированного дохода указывает, тем не менее, на положительный эффект, что входит в противоречие с идеей использования данного показателя для оценки эффективности альтернативных проектов. Такая ситуация характерна для проектов с долгосрочными кредитами и быстрой отдачей от капитальных вложений. Считаем, что подобная ситуация возникает вследствие того, что в расчеты показателей эффективности включаются затраты, которые дисконтируются одновременно с доходами и тем самым, численно увеличивают дисконтированный уровень доходности проекта (при дисконтировании отрицательной величины затрат увеличивается суммарная доходность). Хотя, если исходить из теории ценности денег во времени, именно затраты порождают будущую стоимость - PV. В статье проанализированы рассмотренные противоречия показателей эффективности различных вариантов проектов и предложен новый показатель оценки эффективности проектов.
\end{abstract}

Ключевые слова: денежный поток; эффективный проект; кривая эффективности; чистая приведенная стоимость.

JEL classifications: $O 220$

DOI: https://doi.org/10.33987/vsed.1(69).2019.108-117

\section{Inroduction}

It is generally accepted that there is such an estimation rule of an effective project [2-6; 8-11]:

- if NPV $>0$, PI $>1$, IRR $>\mathrm{i}$ (the project is effective);

- if NPV $<0$, PI $<1$, IRR $<\mathrm{i}$ (the project is not effective);

- if NPV $=0, \mathrm{PI}=1, \mathrm{IRR}=\mathrm{i}$ (zero effectiveness);

where NPV is a net present value, PI stands for profitability index, IRR means internal rate of return, $i$ is a discount rate.

In the article published in 2014 [1], we demonstrated that discount indices of project effectiveness traditionally with used by the majority of theoreticians and analysts did not always represent the actual profitability (unprofitable ness) of the project. This article is an attempt to analyze the new similar project variants in theory and practice and offer the way out of such situations.

\section{Aim and methodology of research}

More generally, the economic efficiency of the project can be defined by the following expression [2, p.103]:

$$
E=f(t, k, R 1 \ldots R n, A),
$$

where $\mathrm{E}$ stands for a complex conversion rate; $\mathrm{t}$ is a time factor; $\mathrm{k}$ means inflation; $\mathrm{R} 1$... Rn means risk factors; $\mathrm{A}$ is the project alternativeness.

\section{Literature review, shortcomings and problem statement}

The function cited above is of little use for practical application because of its multidimensionality. Most of the authors $[2-6 ; 9 ; 10]$ and analysts use a set of efficiency criteria that describe the feasibility of the project from different angles. They use the index of net present value (NPV) as the main indicator of the project profitability which can be updated taking into account the time factor. The given quantity characterizes the general absolute outcome of the investment activity, its final 
effect. NPV stands for the difference between the discounted for a moment incomes measures B (t) and expenditures for the realization of the project $\mathrm{C}(\mathrm{t})$. In this case $\mathrm{t}$ is the number of the year of project life-cycle. If receipts and expenditures are represented as the intake flow, NPV equals the updated variable of the flow. As a majority of authors point out, the variable NPV is the basis for defining other indicators of efficiency $[2-6 ; 9 ; 10]$.

\section{The main material research}

If receipts and expenditures are represented as an intake flow, NPV equals the updated variable of the flow. The variable NPV is a basis for defining other indicators of efficiency. In case the intake flow is characterized by the values $R t=B(t)-C(t)$, which can be both positive and negative, the comparison rate equals $i$, and we get [3]:

$$
N P V=\sum_{t=1}^{n} \frac{B(t)-C(t)}{(1+i)^{n}}=\sum_{t=1}^{n} \frac{R(t)}{(1+i)^{n}} .
$$

When initial expenses $A$ are singled out during the so-called zero period, Formula 1 is changed in the following way:

$$
N P V=\sum_{t=1}^{n} \frac{R(t)}{(1+i)^{n}}-A
$$

Formulas 1, 2 on the one hand represent the function of the project efficiency, on the other hand the numerical series of the cash flow calculation. As an effectiveness function, these formulas offer a complex modification of hyperbola or the power function, the form of which depends on the dynamics of the cash flow, while the numerical series is a modification of the geometric progression, the form of which is also dependent on the dynamics of the cash flow. In many ways these conclusions simplify the analysis approach to the project effectiveness in practice.

Let us consider some peculiarities of calculating NPV for definite kinds of cash flows.

1. If the cash flows of the project are uniformly distributed in time, $R t$ is a constant $=\mathrm{R}$ (constant ordinary annuity). The uniformity of cash flow distribution can be achieved by extending the intervals of planning.

In that case NPV will represent the following numerical series [4]:

$$
N P V=-A-R+\left[R+R \frac{1}{1+i}+R \frac{1}{(1+i)^{2}}+\ldots+R \frac{1}{(1+i)^{n-1}}\right]+R \frac{1}{(1+i)^{n}}
$$

We used square brackets to mark out a classical geometric progression with the general term $q=\frac{1}{1+i} \leq 1$ (series coincide) [4]. After Formula 3 translation we get the following expression:

$$
N P V=-A-R+\frac{R}{1-q}-\frac{R}{1-q} q^{n}+R q^{n}=R \frac{(1+i)^{n}-1}{i(1+i)^{n}}-A .
$$

If Formula 4 is viewed as the efficiency function where $n \rightarrow 0$ (perpetual annuity), equation 4 is rearranged in the form:

$$
N P V=\frac{R}{i}-A
$$

Let us analyze a similar simple variant. In this case the project efficiency depends on the comparison rate $i$ and combination of $\mathrm{R}$ and $\mathrm{A}$. If $\mathrm{A}=0$, we have a classical hyperbola (Fig. 1, 
negative values of discount rates are given conditionally). In this case the stability of the project is absolute, while IRR $\rightarrow \infty$. Can we have such cases in practice?

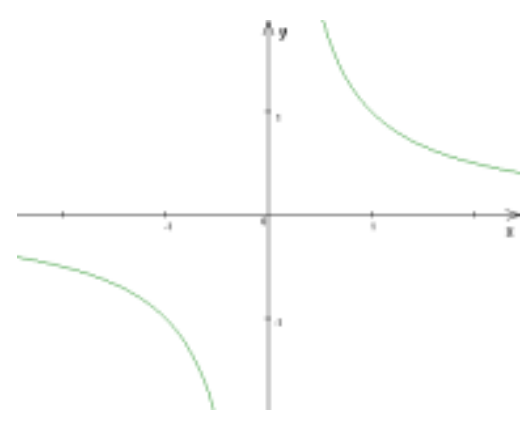

Fig. 1. Classic hyperbole

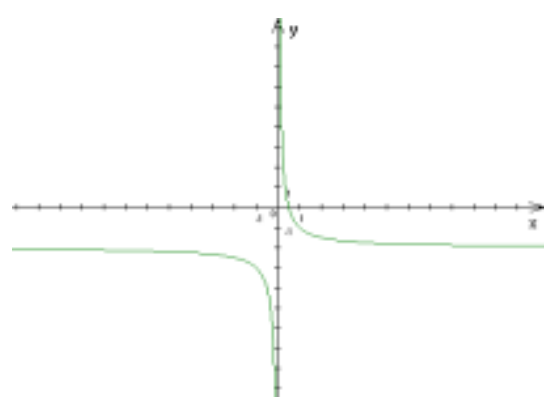

Fig. 2. Classic efficiency curve

Yes, we can, if the initial investments are diffused in the years of life-cycle or are completely lacking (sponsorship, investments out of proceeds of credit, etc.).

If the initial investments are used in zero period the shape of the function of effectiveness depends on the combination of R and A (Fig. 2). IRR can be defined with the help of the expression $N P V=\frac{R}{i}-A=0 \rightarrow i=\frac{R}{A}$. That is why the forecasting models, based on the cash flow uniformity can have high IRR.

\section{Research results}

Let us analyze the general approach to the effectiveness function using Formula 1. We may have variants in this case as well. The most interesting are [5]:

- decrease of the cash flow by the end of the life cycle of the project;

- increase of the cash flow by the end of the life cycle of the project;

- fluctuation of the of the cash flow during the life cycle of the project;

- at last one more variant is possible when $N P V=\sum R(t)$ (net present value is more than total net profit).

Let us study the first case - decrease of the cash flow by the end of the life cycle of the project (Fig. 3).

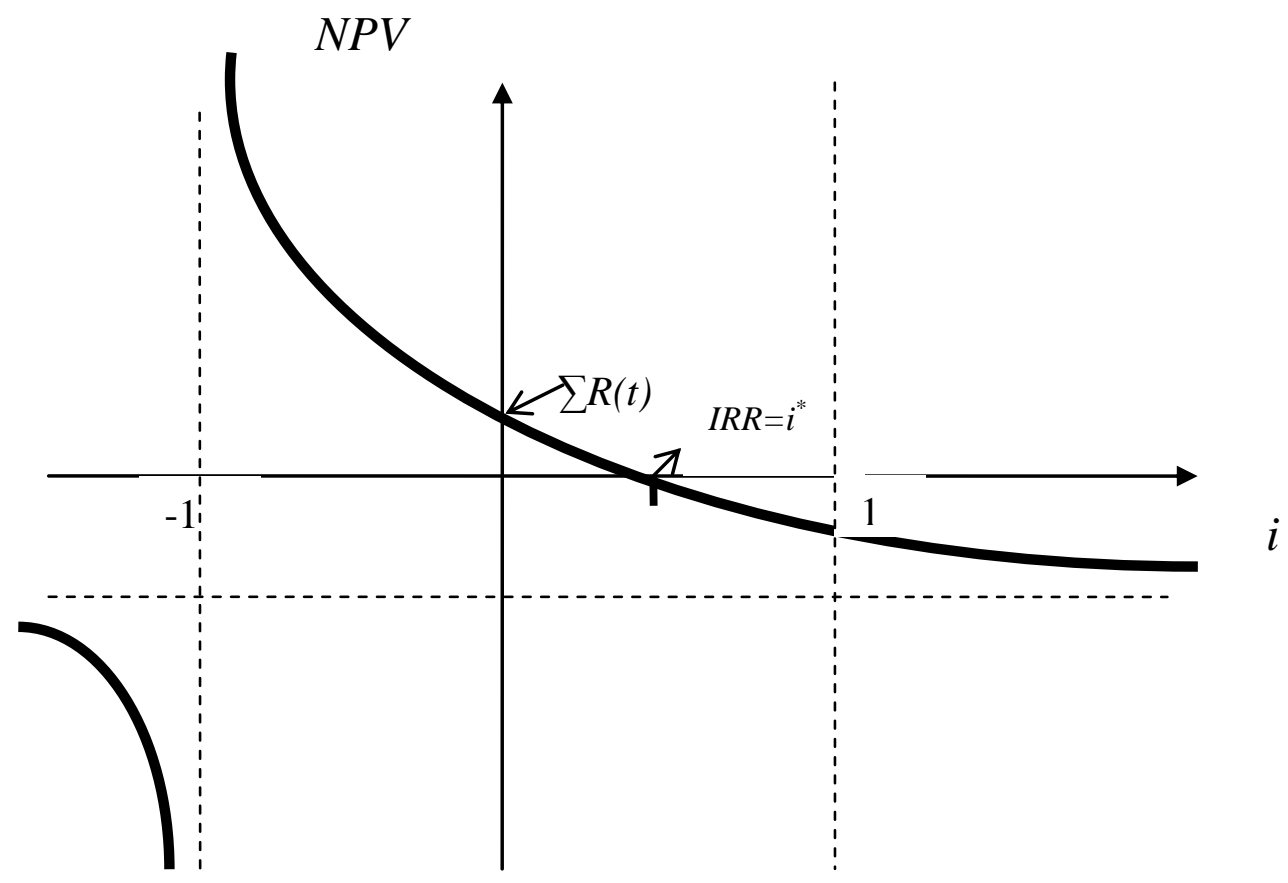

Fig. 3. Reduction of cash flow to the end of the project life cycle 
The effectiveness curve starts at point $\sum R(t)$ when $i=0$ (we do not take into consideration the negative values of comparison rates in our article) and drops dramatically to the critical value $I R R$ when $N P V=0$. Further with $i$ growth, $N P V \leq 0$.

The second option is increase of the cash flow by the end of the life cycle of the project (Fig. 4).

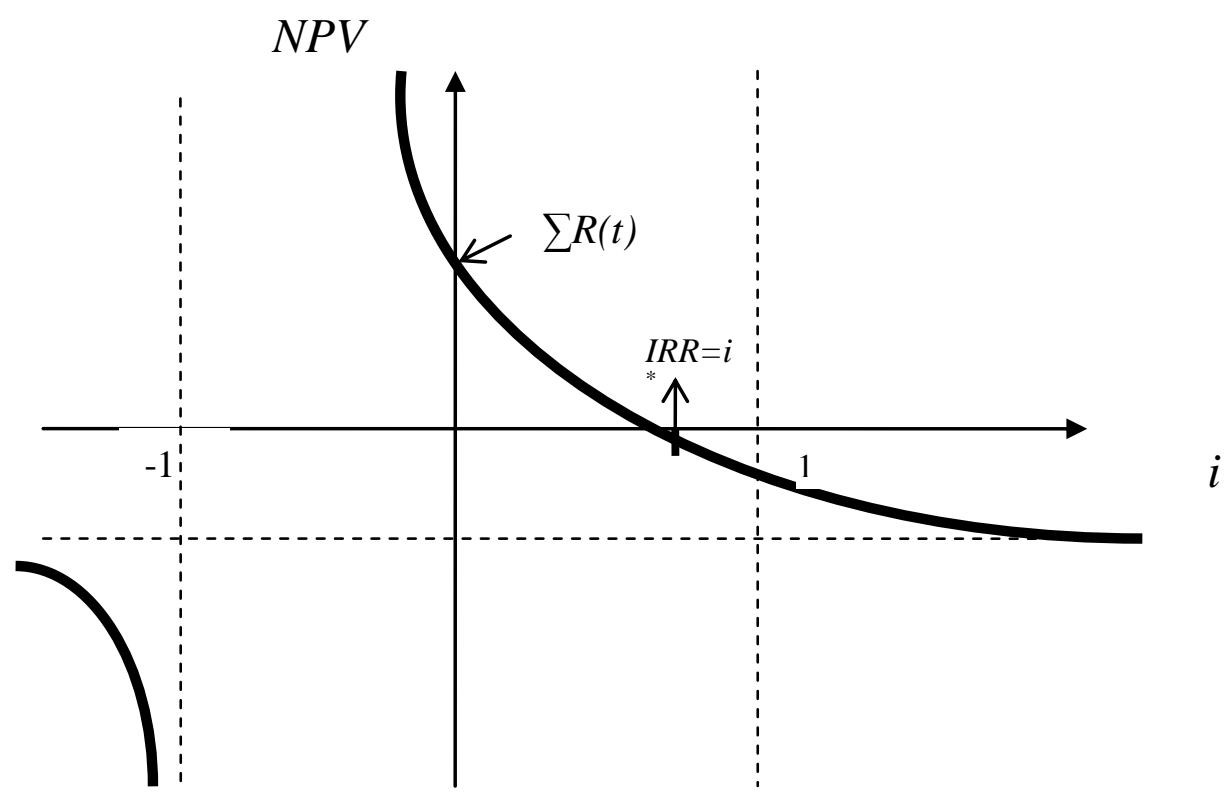

Fig. 4. Increase the cash flow to the end of the project life cycle

This variant repeats the previous one in its shape but has a much higher point of total cash flow $\sum R(t)$ and larger IRR (other conditions being equal). Software products for automatic calculations of project efficiency mostly use two models of cash flow growth [1]. In the first model the cash flow growth takes place before the project capacity saturation (Fig. 5) reaching some point (M), then the level of cash flow flattens till the end of the project life cycle. The second model is closely associated with the life cycle of the project. It means a gradual growth of the cash flows (Fig. 6) to demand saturation (point P), followed by stabilization on this level while maintaining the given value of service, next followed by decrease to the extent of recession in demand for goods.

Net cash flow

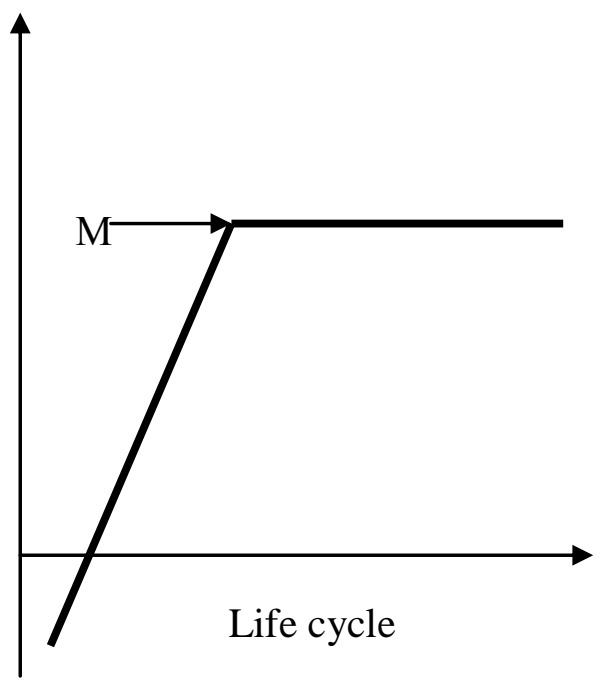

Fig. 5. Saturation of project capacities
Net cash flow

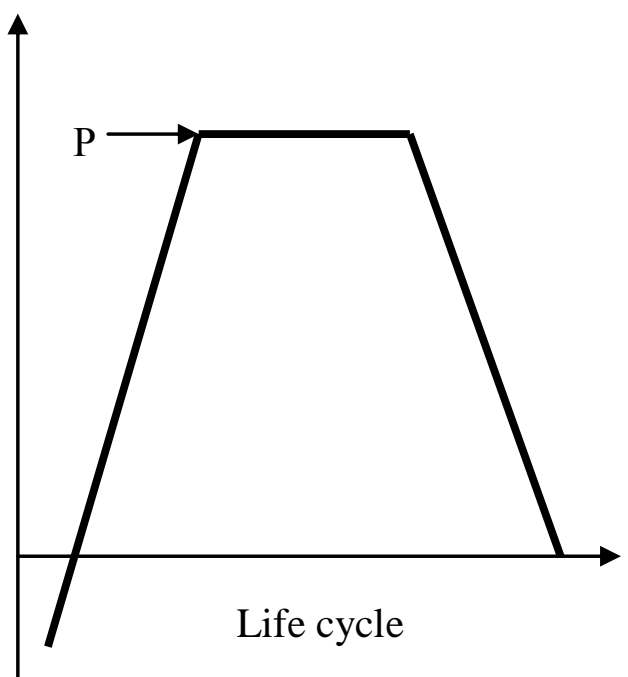

Fig. 6. Reduced capacity as demand falls on the product 
The first model has an effectiveness curve that is closer to the graphic chart of Fig. 4, the second one is closer to the graphic chart of Fig. 3.

In the third case of the practically investigated cash flows the relation will not be so facile and "correct" as in Fig. 3 and 4. The picture of the examined relation changes if the members of the flow reverse signs more than once [5] for example as a result of the fact that some years later after the beginning of the return, modernization of production may be provided, which requires considerable expenses. In this case the graphic chart showing relation between $N P V$ and $i$ will differ significantly from the graph in Fig. 3 and 4. Thus Fig. 7 demonstrates the condition when the variable NPV reverses its sign three times.

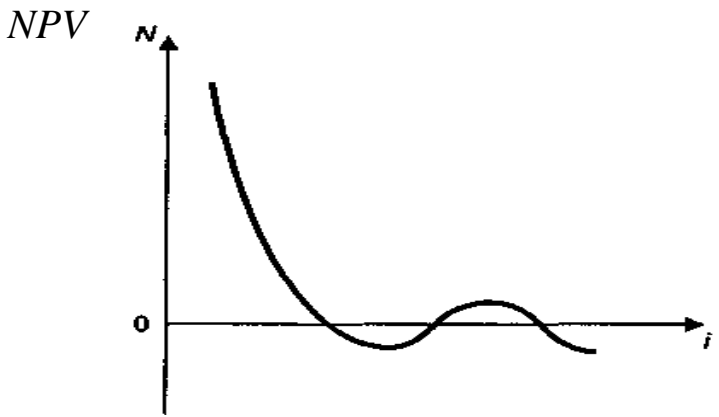

Fig. 7. The NPV value changes its sign three times from the plus to minus

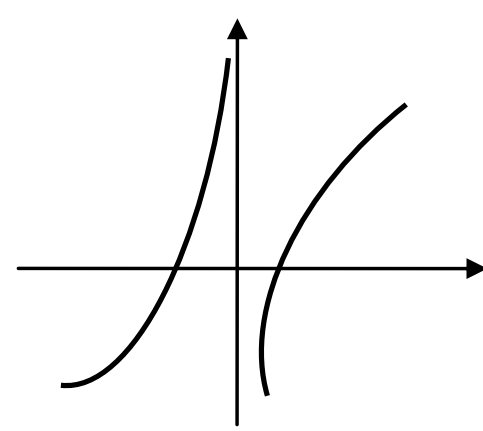

Fig. 8. The cash flow changes its sign from the minus plus

However, in all three cases that we have examined the sign of the cash flow is reversed from the negative to the positive one, in the latter case from minus to plus, then to minus again and so on.

Theoretically the reversed situation is possible when the cash flow reverses a sign from plus to minus (not in zero period). In such a case we can get the effectiveness curve like the one in Fig. 8.

At the same time there might be situations with calculating NPV, when NPV $\geq \sum \mathrm{R}$ (total net cash flow). Such a situation may seem impossible based on expressions 1 and 2 . Let us study the situation of illustrative example 1 (Tab. 1).

Table 1

Illustrative example of cash flow calculation of project 1

\begin{tabular}{|c|c|c|c|c|c|c|c|c|}
\hline Initial expenses & 10 & \multirow{2}{*}{ Activities } & \multicolumn{5}{|c|}{ Periods } & \multirow{2}{*}{ Total } \\
\hline Discount rate & 0,15 & & 1 & 2 & 3 & 4 & 5 & \\
\hline Units of cash flow & $\begin{array}{c}\text { Standard } \\
\text { unit }\end{array}$ & $\begin{array}{l}\text { Current } \\
\text { expenses }\end{array}$ & 0 & 0 & 0 & 0 & 50 & 50 \\
\hline Life cycle of the project & 5 & Revenue & 0 & 0 & 40 & 10 & 10 & 60 \\
\hline
\end{tabular}

When the discount rate is on the level of $0,15(15 \%)$, the initial expenses in the zero period are 10 standard units, and the cash flow distribution is as shown in table 1, we have a zero net cash return $\left(\sum \mathrm{R}=-10-50+40+10+10=0\right), \quad$ however $\quad N P V=-10+\frac{40}{(1+0.15)^{3}}+\frac{10}{(1+0.15)^{4}}+\frac{10-50}{(1+0.15)^{5}}=2.13$.

It seems to contradict the fundamental postulate of project efficiency - if NPV $>0$, the project is effective. However, for crisis project variants the problem situation $\sum \mathrm{R}=0$ remains, which makes the project effective. Let us calculate the effectiveness curve for our example 1 (Tab. 2). 
Table 2

Calculation of the effectiveness curve of illustrative example 1

\begin{tabular}{|c|r|r|r|r|r|r|r|r|r|r|r|r|r|}
\hline$i$ & 0,00009 & 0,001 & 0,1 & 0,15 & 0,2 & 0,3 & 0,4 & 0,5 & 0,6 & 0,7 & 0,8 & 0,9 & 1 \\
\hline$N P V$ & 0,0035 & 0,003 & 2,04 & 2,13 & 1,89 & 0,93 & $-0,25$ & $-1,44$ & $-2,5$ & $-3,5$ & $-4,3$ & -5 & $-5,6$ \\
\hline
\end{tabular}

As we see from the table information and the effectiveness curve based on it (Fig. 9), NPV maximizes from 0 at point $i=0.15, \mathrm{NPV}=2.13$, then it drops to point $\mathrm{IRR}=0.38$ and below 0 .

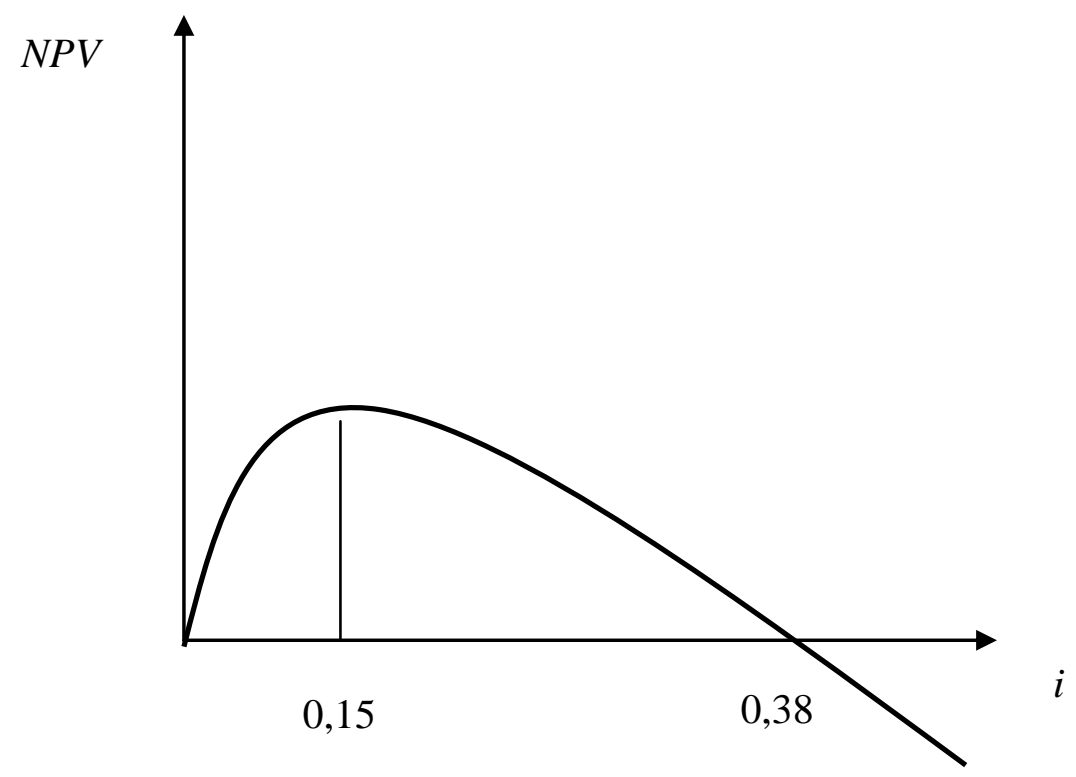

Fig. 9. Performance curve of illustrative example $1\left(\mathrm{NPV}>0, \sum \mathrm{R}=0\right)$

However, as our experience has shown, such a situation is quite possible in practice for quite successful projects. If the project has moderate volumes of current expenses, which, for example, are realized against credit or some other ways of borrowing with a considerable delay of credit payment, we may have non-recurring incomes from the project at one of the initial stages. These non-recurrent incomes can significantly exceed current costs. Credit repayments take place at the end of the project life cycle. In this case it is possible to have the situation NPV $>\sum R>0$.

Let us examine the situation. A credit for capital costs was given for project 2 . The credit is at the amount of 30 standard units at annual interest $16,7 \%$ for 5 years on condition of paying off at the end of the period. The results of realizing the project with the life cycle of 5 years and the annual comparison rate of $15 \%$ are represented in Tab. 3 .

Table 3

Illustrative example of cash flow calculation of project 2

\begin{tabular}{|c|c|c|c|c|c|c|c|c|}
\hline Initial expenses & 30 & \multirow{2}{*}{ Activities } & \multicolumn{5}{|c|}{ Periods } & \multirow{2}{*}{ Total } \\
\hline Discount rate & 0,15 & & 1 & 2 & 3 & 4 & 5 & \\
\hline Units of cash flow & $\begin{array}{l}\text { Standard } \\
\text { units }\end{array}$ & $\begin{array}{l}\text { Current } \\
\text { expenses }\end{array}$ & 0 & 0 & 0 & 0 & 65 & 65 \\
\hline Life cycle of the project & 5 & Revenue & 50 & 20 & 10 & 0 & 0 & 80 \\
\hline
\end{tabular}

According to the credit conditions the amount of payment will be 65 standard units at the end of the fifth year.

In terms of the results of the project we have $\sum \mathrm{R}=-30+50+20+10-65=-15$ standard units, and $N P V=-30+\frac{50}{(1+0.15)^{1}}+\frac{20}{(1+0.15)^{2}}+\frac{10}{(1+0.15)^{3}}-\frac{65}{(1+0.15)^{5}}=2.86$ st.monet.unit 
In this case we have NPV $>0>\sum R<0$. It is a positive NPV in an inefficient project.

Let us calculate the effectiveness curve for our example 2 (Tab. 4).

Calculation of effectiveness curve of illustrative example 2

Table 4

\begin{tabular}{|c|c|c|c|c|c|c|c|c|c|c|c|c|c|}
\hline$i$ & 0,00009 & 0,001 & 0,1 & 0,15 & 0,2 & 0,3 & 0,4 & 0,5 & 0,6 & 0,7 & 0,8 & 0,9 & 1 \\
\hline$N P V$ & $-14,99$ & $-14,79$ & $-0,86$ & 2,86 & 5,2 & 7,3 & 7,47 & 6,62 & 5,3 & 3,79 & 2,2 & 0,69 & $-0,78$ \\
\hline
\end{tabular}

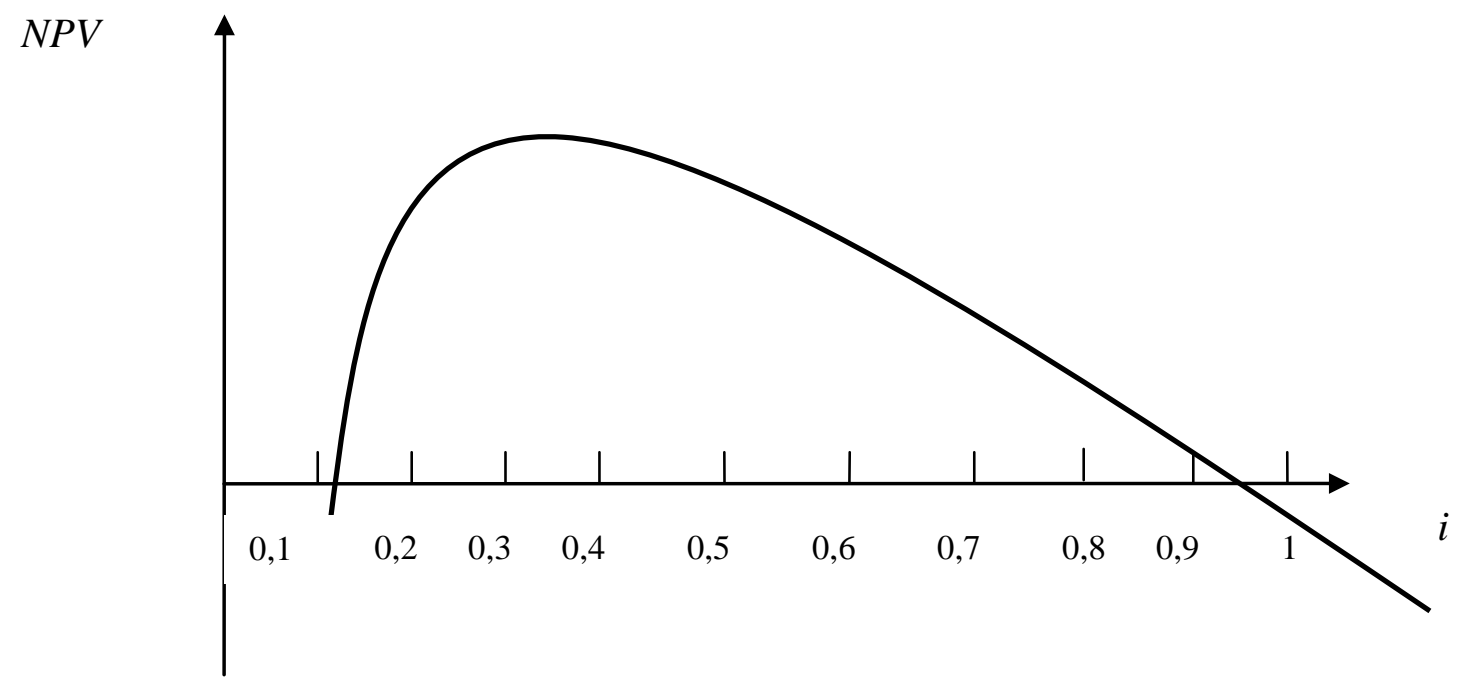

Fig. 10. Performance curve of illustrative example $2\left(\mathrm{NPV}>0, \sum \mathrm{R}<0\right)$

As we see from the information in the table and the effectiveness curve based on it (Fig. 10), NPV at two points equals 0 (if $i=0,11$ and 0,946 ), the maximum is between the points $i=0.3$ and 0,4 , $\mathrm{NPV}=7,47$, there may be equality between NPV and $\sum \mathrm{R}$ at the point $i=3$.

As calculations given above show, the measures of project efficiency, based on calculating $N P V$ do not always render the actual effectiveness of the project (variant in Tab. 3).

In our opinion, such a situation can arise as a result of including expenses into the calculation of measures of effectiveness, which discount at the same time with the revenue, thereby they computationally increase the discount level of project profitability (as a result of discounting the negative value of expenses the total rate of return increases. Though, if one accepts the premise of the theory of time value of money [10, p.353], it is the expenses that influence the present value $P V$. That is in every period of time $t$ costs $C(t)$ give rise to future earnings $B(t)$. In its semantic loading $C(t)$ is the initial value $P$ for a future earnings-flow during $t$ period. That is why we think it is not advisable to include the costs into the discount part of the measure of project effectiveness.

In order to evaluate the general effectiveness of the project it is possible to offer the index of total discount revenue deducting the total project expenditure during the whole life cycle of the project $(P V N C)$ :

$$
P V N C=\sum_{t=1}^{n} \frac{R(t)}{(1+i)^{n}}-\sum_{t=0}^{n} C(t) .
$$

Let us analyze the use of formula 5 to evaluate the above mentioned examples of projects.

Zero value of $P V N C$ index is obtained for the projects in which the total discount revenue equals the total expenditure:

$$
\sum_{t=1}^{n} \frac{R(t)}{(1+i)^{n}}-\sum_{t=0}^{n} C(t)=0 \Rightarrow \sum_{t=1}^{n} \frac{R(t)}{(1+i)^{n}}=\sum_{t=0}^{n} C(t)
$$


The calculations showed that for project $1 \sum R=0, N P V=2.13, P V N C=-23.16<0$. For project 2 $\sum R=-15, N P V=2.86, P V N C=-29,8<0$.

Thus, according to the index $P V N C$, both projects are ineffective because total discount revenues do not cover the total project expenditure.

Table 5

Illustrative example of calculating $N P V$ and $P V N C$ of project 3

\begin{tabular}{|c|c|c|c|c|c|c|c|c|}
\hline Initial expenses & 80 & \multirow{2}{*}{ Activities } & \multicolumn{5}{|c|}{ Periods } & \multirow[b]{2}{*}{ Total } \\
\hline Discount rate & 0,15 & & 1 & 2 & 3 & 4 & 5 & \\
\hline \multirow{2}{*}{ Units of cash flow } & \multirow{2}{*}{$\begin{array}{l}\text { Standard } \\
\text { units }\end{array}$} & $\begin{array}{l}\text { Current } \\
\text { expenses, }\end{array}$ & 0 & 0 & 0 & 0 & 1000 & 1000 \\
\hline & & $\begin{array}{l}\text { General } \\
\text { project costs }\end{array}$ & - & - & - & - & - & 1080 \\
\hline $\begin{array}{l}\text { Life cycle of the } \\
\text { project }\end{array}$ & 5 & Revenue & 390 & 350 & 360 & 210 & 240 & 1550 \\
\hline & & $\sum \mathrm{R}$ & 470 & & & & & \\
\hline & & NPV & 502,7 & & & & & \\
\hline & & PVNC & $-0,123$ & & & & & \\
\hline
\end{tabular}

In practice it is often possible to come across projects which have the growing current cost, connected with its liquidation, at the end of economic life. The numerical illustration of such project 3 is presented in Tab. 5 .

As we see from table $5, \mathrm{NPV}=502,7>\sum \mathrm{R}=470$, which completely distorts the fundamental postulates of the theory of time value of money. In fact, the total discount revenues do not cover the total costs of the project $\sum_{t=1}^{n} \frac{R(t)}{(1+i)^{n}}=1079.9<\sum_{t=0}^{n} C(t)=1080$, they are about equal, the index PVNC $=-0,123$ is approximate to zero. Taking into consideration the value PVNC, project 3 from the point of view of the theory of time value of money has zero efficiency.

\section{Conclusions}

1. The rule NPV $>0$, PI $>1$, IRR $>i$ is not always true. In some variants of project realization (sponsorship, credit with deferral of payments, other forms of investment at the cost of borrowed funds, as well as projects, which have growing current cost at the end of economic life, the cost exceeds the project revenue, which stops the whole project). This rule does not always represent the real profitability (unprofitableness) of the project. For such projects we suggest counting the index of the total discount revenue with the deduction of total project expenditure during the whole project life cycle $-P V N C$, if its value is below zero. Such a project should be turned down, as total discount revenue does not cover the total project expenditure.

2. The calculation of conversion rate is to be accompanied by the economic analysis of the project cash flow.

\section{References}

1. Karpov, V. A., Batanova, T. V. (2014). New vision of the rule of positive value of net discount profit for effective projects [Nove bachennia pravyla pozytyvnoho znachennia chystoho dyskontovanoho dokhodu dlia efektyvnykh proektiv], Vìsnik socìal'no-ekonomičnih doslìdžen', No. 2 (53), s. 71-77 [in Ukrainian]

2. Karpov, V. A., Ulybina, V. O. (2006). Project analysis [Proektnyi analiz], OSEU, Odessa, 150 s. [in Ukrainian]

3. Volkov, I. M., Grachyova, M. V. (1998). Project analysis [Proektnyy analiz], Banki i birzhi, Moskva [in Russian] 
4. Kudryavtsev, V. A., Demidovych, B. P. (1975). Short course of higher mathematics [Kratkiy kurs vysshey matematiki], Nauka, Moskva, 559 s. [in Russian]

5. Gorbachenko, S. A., Karpov, V. A. (2013). Analysis of entrepreneurial projects [Analiz pidpryiemnytskikh proektiv], OSEU, Odessa, $241 \mathrm{~s}$. [in Ukrainian]

6. Avanesov, E. T., Kovalyov, M. M., Rudenko, V. G. (2002). Investment analysis [Investitsionnyy analiz], Minsk, BGU, 247 s., available at: http://www.elobook.com [in Russian]

7. Blank, I. A. (2001). Investment management [Investitsionnyy menezhment], Nika-tsentr, Moskva, $448 \mathrm{~s}$. [in Russian]

8. Savchuk, V. P., Prilirko, E. G., Velichko, O. K. (2000). Analysis and design of investment projects [Analiz i razrabotka investitsionnykh proektov], Absolyut-V, Kiev, 304 s. [in Russian]

9. Sokolova, O. E., Sulima, L. O. (2011). Project analysis [Proektnyi analiz], NAU, Kyiv, 86 s. [in Ukrainian]

10. Brighem, E. F., Ehrhardt, M. S. (2010). Financial management. $10^{\text {th }}$ ed. [Finansovyy menezhment; 10 izd.], Piter, Sankt-Peterburg, 960 s. [in Russian]

11. Kucherenko, V. R., Karpov, V. A., Markitan, O. S. (2006). Firm's business-planning [Biznesplanuvannia firmy], Znannia, Kyiv, 425 s. [in Ukrainian] 